\title{
Proses Pengembangan Suku Bajo Di Desa Pulau Bungin Kecamatan Alas Kabupaten Sumbawa
}

\author{
Andi Mulyan \\ Program Studi Pendidikan Sosiologi \\ Fakultas Pendidikan \\ Universitas Nahdlatul Ulama NTB \\ Andimulyan2018@gmail.com
}

\begin{abstract}
Abstrak; Desa Pulau Bungin Kecamatan Alas Kabupaten Sumbawa. Bahwa perluasan wilayah Desa Pulau Bungin terjadi karena lokasi tersebut sangat strategis untuk mencari penghidupan, yaitu bekerja sebagai nelayan, sehingga banyaknya nelayan Suku Bajo yang akan menetap, namun tidak ada lahan tempat tinggal, terpaksa mereka harus mengumpulkan batu karang dari laut untuk dijadikan bahan timbunan pada tepi laut yang mana sebagai tempat mendidirikan rumah panggung khas Sulawesi Selatan. Karena persoalan lahan tempat tinggal tidak ada, pada akhirnya tradisi mengumpulkan batu karang dari laut telah menjadi kewajiban bagi warga yang akan melangsungkan pernikahan yaitu sebagai bahan timbunan di tepi laut dan akan mendirikan rumah panggung. Pertumbuhan penduduk di wilayah ini terjadi secara alami oleh pernikahan, baik pernikahan sesama warga maupun dengan pihak luar dan akan menetap di wilyah ini untuk bekerja sebagai nelayan dan menghasilkan ketuunan sehingga mempengaruhi laju pertumbuhan penduduk, yang akhirnya pula mempengaruhi perluasan wilayah. Selain itu, proses pengembangan pulau kecil ini didasari oleh kebutuhan masyarakat dalam mengembangkan diri dari berbagai aspek. Namun suatu kendala yang harus diterobos, yaitu kesulitan untuk berinteaksi dengan desa lain, sehingga dengan solidaritas, kekeluargaan, pembagian yang mana mereka saling membahu untuk membuat infrastruktur jalan di atas laut yang sebagai penghubung pulau ini dengan desa luar untuk saling berintearksi dan dalam memenuhi berbagai kebutuhan mereka. Setelah terwujud infrastruktur jalan di atas laut, yang mana berbagai aspek kehidupan telah berkembang di desa pulau ini, baik dari aspek pendidikan, ekonomi, dan sebagainya. Hal inilah yang membuat peneliti sangat tertarik mengkaji lebih dalam tentang proses perluasan wilayah dan pertumbuhan penduduk di pulau kecil ini, dan juga tentang proses pengembangan masyarakat di wilayah ini dengan menggunakan jenis penelitian dasar dan pendekatan kualititatif, serta metode deskriptif kulaitatif dengan mengandalkan bentuk wawancara, observasi, maupun dokumentasi, serta menggunakan teori-teori sebagai bahan pisau analitik. Penelitian ini berjudul, “ Proses Pengembangan Suku Bajo Di Desa Pulau Bungin Kecamatan Alas Kabupaten Sumbawa."
\end{abstract}

\section{Kata Kunci: Pengembangan Suku Bajo}

\section{PENDAHULUAN}

Indonesia merupakan suatu negara kepulauan terbesar di Dunia, yang terdiri dari 17.508 pulau dan garis pantai sepanjang $81.000 \mathrm{~km}$ (terpanjang ke dua di Dunia setelah Canada) serta wilayah laut teritorial seluas 5,1 juta $\mathrm{km}^{2}$ (63\% dari total wilayah teritorial Indonesia), ditambah dengan Zona Ekonomi Eksklusif seluas 2,7 juta $\mathrm{km}^{2}$, sesungguhnya Indonesia memiliki potensi sumberdaya alam pesisir dan lautan yang sangat besar dan beraneka- ragam. Dari sekian ribu pulau tersebut, sebagian besar merupakan pulau-pulau kecil yang jumlahnya lebih dari 10.000 buah.

Provinsi Nusa Tenggara Barat memiliki 280 Pulau, termasuk pulau-pulau ternama yang sering dikunjungi oleh para wisatawan. Salah satu pulau yang sering dikunjungi oleh wisatawan yaitu Pulau Bungin, dan merupakan bagian dari 280 Pulau yang ada di Nusa Tenggara Barat. Pulau nelayan ini merupakan sebuah desa nelayan yang dihuni oleh suku Bajo, dan jumlah penduduknya sangat padat sehingga tidak seimbang dengan luas wilayah hunian. 
Pulau Bungin merupakan salah satu pulau yang terletak di Kecamatan Alas Kabupaten Sumbawa Nusa Tenggara Barat. Pengakuan warga setempat, asal terbentuknya pulau ini adalah diawali dengan ditemukannya sebuah gundukan pasir berupa daratan yang muncul di permukaan laut, yaitu didekat Kecamatan Alas Sumbawa. Kemunculan sebuah daratan kecil di atas permukaan laut disebut "Bungin" dalam bahasa Bajo. Akhirnya daratan itu dinamakan Bungin.

Informasi dari warga setempat bahwa pada zaman dulu yaitu seorang pelaut asal Sulawesi Selatan menemukan daratan kecil tersebut, akhirnya membangun sebuah mushollah di atas daratan kecil itu yang luasnya hanya berkisar $7 \times 8$ meter. Adapun ukuran mushollah yang dibangun pada waktu itu adalah hanya berukuran 4 X 5 meter persegi. Mushollah atau masjid kecil itu pun diberi nama "Masjid Bungin".

Keberadaan masjid kecil di atas daratan kecil tersebut, akhirnya seorang nelayan bugis lagi mendirikan sebuah rumah panggung di dekat masjid kecil itu. Bangunan rumah panggung tersebut diawali dengan mengumpulkan batu karang dari laut untuk dijadikan sebagai timbunan di tepi lokasi masjid kecil itu. Di atas timbunan batu karang itulah dibangun sebuah rumah panggung. Pada saat itu, yang mana ketika seorang nelayan yang akan mampir di masjid kecil itu, ia pun selalu mengatakan mampir di pulau bungin, sehingga lokasi ini sangat familiar dengan sebutan Pulau Bungin.

Dari dan tahun ke tahun, pulau ini selalu mengalami perkembangan, baik dari aspek fisik maupun aspek non fisik. Dari aspek fisik dimana masyarakat setempat selalu bergeliat untuk melakukan perluasan wilayah, yang mana dalam hal ini sangat dipengaruhi oleh laju pertumbuhan penduduk yang selalu mengalami peningkatan. Sampai kini, luas wilayah Pulau Bungin sudah mencapai sekitar tujuh hektar. Berdasarkan data statitik dari Kantor Desa Puau Bungin bahwa seiring dengan perluasan wilayah tersebut yang mana jumlah penduduknya pun semakin meningkat. Kepadatan penduduk di wilayah ini sudah mencapai 14.133 jiwa/km persegi. Hal ini sudah menunjukkan tidak adanya keseimbangan antara jumlah penduduk dengan lokasi pemukiman. Hal ini pula menjadikan Pulau Bungin terkenal sebagai "Pulau Terpadat Di Dunia".

Dari aspek non fisik, penduduk Desa Pulau Bungin tergiring utuk mengalami perkembangan dari berbagai aspek pendidikan, ekonomi, politik dan sebagainya. Sofyan (60 th) adalah salah seorang mantan Kepala Desa Pulau Bungin mengatakan bahwa sangat berbeda pada sebelum tahun 2000 , yang mana perkembangan masyarakat di desa pulau ini masih sangat tertinggal, terutama dalam aspek pendidikan dan perekonomian. Dari hal ini dapat dipahami bahwa pengembangan Pulau Bungin tentu memiliki suatu proses yang yang cukup unik untuk dikaji, terlebih jika dilihat dari letak gegrafisnya yang berada di tengah laut dan sangat terpencil.

Berangkat dari hal tersebut di atas, penulis sangat tertarik untuk mengkaji tentang proses pengembangan masyarakat yang terjadi di Desa Pulau Bungin, dan juga akan mengkaitkan dengan proses perluasan wilayah serta pertumbuhan penduduk di wilayah ini. Berangkat dari permasalahn tersebut, dalam penelitian ini diangkat judul "Proses Pengembangan Masyarakat Suku Bajo Di Desa Pulau Bungin Kecamatan Alas Kabupaten Sumbawa".

\section{Rumusan Masalah}

1.Bagaimana proses perluasan wilayah dan pertumbuhan penduduk pada Suku Bajo Di Desa Pulau Bugin Kecamatan Alas Kabupaten Sumbawa.

2. Bagaimana proses pengembangan pada masyarakat Suku Bajo yang ada di Desa Pulau Bungin Kecamatan Alas Kabupaten Sumbawa.

\section{Tujuan Penelitian}

1. Mengetahui proses perluasan wilayah dan pertumbuhan penduduk yang ada pada masyarakat Suku Bajo Di Desa Pulau Bugin Kecamatan Alas Kabupaten Sumbawa.

2. Mengetahui proses pengembangan pada masyarakat Suku Bajo yang ada di Desa Pulau Bungin Kecamatan Alas Kabupaten Sumbawa. 


\section{Manfaat Penelitian}

\section{- Manfaat Teoritis}

3. Agar hasil penelitian tentang perluasan wilayah, pertumbuhan penduduk, dan proses pengembangan masyarakat pada Suku BAjo yang ada di Desa Pulau Bungin Kecamatan Alas Kabupaten Sumbawa menjadi referensi bagi peneliti selanjutnya.

4. Agar hasil penelitian tentang perluasan wilayah, pertumbuhan penduduk, dan proses pengembangan masyarakat Suku Bajo di Desa Pulau Bungin Kecamatan Alas Kabupaten Sumbawa dapat menjadi referensi bagi penulis atau jurnalis, baik di kalangan mahasiswa, maupun dikalangan umum.

- Manfaat Praktis

1. Agar hasil penelitian tentang proses perluasan wilayah, pertumbuhan penduduk, dan proses pengembangan masyarakat Suku Bajo di Desa Pulau Bungin Kecamatan Alas Kabupaten Sumbawa dapat menjadi acuan bagi pemerintah dalam menindaklanjuti atau lebih meningkatkan pola pengembangan masyarakat.

2. Agar hasil penelitian tentang proses perluasan wilayah,pertumbuhan penduduk, dan proses pengembangan masyarakat dalam berbagai aspek kehidup bermasyarakat yang ada di Desa Pulau Bungin Kecamatan Alas Kabupaten Sumbawa dapat menjadi acuan bagi masyarakat desa dalam mengembangkan pola perkembangan hidup.

\section{Landasan Teori}

A. Konsep Pengembangan masyarakat

Pada hakikatnya bahwa semua pembangun dilaksanakan agar mampu meningkatkan kesejahteraan masyarakat. Olehnya itu, pembangunan terhadap masyarakat desa dipusatkan pada mereka (people centered development) (Korten, 2001:110), melalui suatu gerakan yang dinamakan pengembangan masyarakat (community development) sebagaimana rumusan konsep Brokensha dan Hodge dalam Adi (2003:200) berikut ini : Community development is a movement designed to promote better living for the whole community with the active participation and on the initiative of the community (Pengembangan masyarakat adalah suatu gerakan yang dirancang guna meningkatkan taraf hidup keseluruhan masyarakat melalui partisipasi aktif dan inisiatif dari masyarakat).

Definisi di atas menggambarkan bahwa adanya upaya untuk meningkatkan kemampuan masyarakat serta berusaha menciptakan suatu kondisi yang memancing kemauan dan insiatif sendiri dari masyarakat yang bersangkutan. Dari peningkatan kemampuan dan inisiatif mereka, mereka diharapkan agar semakin mandiri dan mampu memahami permasalahan yang dihadapi serta potensi yang mereka miliki untuk dimanfaatkan semaksimal mungkin.

Selain itu, Dunham dalam Adi (2003:218) mengatakan bahwa dalam konsep pengembangan masyarakat, yang mana pengembangan masyarakat merupakan : "Organized efforts to improve the conditions of community life, primarily through the enlistment of self-help and cooperative effort from the villagers, but with technical assistance from government or voluntary organizations".

(berbagai upaya yang terorganisir yang dilakukan guna meningkatkan kondisi kehidupan masyarakat, terutama melalui usaha yang kooperatif dan mengembangkan kemandirian dari masyarakat pedesaan, tetapi hal tersebut dilakukan dengan bantuan teknis dari pemerintah ataupun lembaga-lembaga sukarela).

Terkait dengan hal tersebut, Dunham juga menjelaskan bahwa pengembangan masyarakat mencakup : 1) program terencana yang difokuskan pada seluruh kebutuhan masyarakat, 2) bantuan teknis, 3) berbagai keahlian yang terintegrasi untuk membantu masyarakat, dan 4) suatu penekanan utama atas self help dan partisipasi oleh masyarakat. Namun, Dunham dalam Adi (2003:218-219) juga mengatakan bahwa dalam usaha menggambarkan pengembangan masyarakat, yang mana terdapat 5 (lima) prinsip dasar yang amat penting, yakni : 1.Penekanan pada pentingnya kesatuan 
kehidupan masyarakat dan hal yang terkait dengan hal tersebut 2.Perlu adanya pendekatan antar tim dalam pengembangan masyarakat 3.Kebutuhan akan adanya community worker yang serba bisa (multi purpose) pada wilayah pedesaan

4.Pentingnya pemahaman akan pola budaya masyarakat

lokal

5.Adanya prinsip kemandirian yang menjadi prinsip utama dalam pengembangan masyarakat.

Selain hal di atas, RG Squad, suatu pengembangan masyarakat atau pembangunan masyarakat haruslah merata, baik di pusat pertumbuhan dan daerah sekitarnya. Tujuannya, agar kedua wilayah dapat tumbuh dan berkembang bersama sehingga saling menguntungkan. Berikut penjelasan mengenai pembangunan dan pengembangan wilayah.

Pembangunan adalah upaya secara sadar dari manusia untuk memanfaatkan lingkungan dalam usaha memenuhi kebutuhan hidupnya. Dengan adanya pembangunan, kehidupan dan kesejahteraan manusia dapat meningkat.

Tujuan pembangunan dapat tercapai dengan memerhatikan berbagai permasalahan, di antaranya:

1. Pengendalian pertumbuhan penduduk dan kualitas sumber daya manusia.

2. Pemeliharaan daya dukung lingkungan.

3. Pengendalian ekosisitem dan jenis spesies sebagai sumber daya bagi pembangunan.

4. Mengantisipasi krisis energi sebagai penopang utama industrialisasi.

\section{Teori Perubahan Sosial}

Perkembangan suatu masyarakat sangat relefan dengan proses terjadinya perubahan sosial di suatu masyarakat. Dalam arti bahwa dengan adanya suatu perubahan sosial yang terjadi pada suatu kelompok masyarakat sudah barang tentu akan menghasilkan bentuk atau wujud dari suatu model perkembangan masyarakat. Namun dalam hal ini, Quipperian memiliki kecenderungan melihat bahwa terjadinya suatu perubahan sosial adalah karena adanya suatu gejala yang wajar dalam kehidupan sosial. Perubahan sosial akan terus berlangsung dan perkembangannya tidak akan berhenti. Ada beberapa teori yang menjelaskan tentang fenomena perubahan sosial ini, antara lain adalah sebagai berikut:

1. Teori Evolusi

Teori evolusi mungkin sering kita dengar dalam ilmu Biologi dan secara garis besar, kalian juga pasti mengetahui inti dari teori ini. Penjelasan Teori Evolusi dalam ilmu sosial juga tidak jauh berbeda. Teori evolusi menjelaskan bahwa perubahan sosial terjadi secara lambat untuk waktu yang lama di dalam sistem masyarakat.

Dari teori di atas, perubahan sosial terjadi karena perubahan pada cara pengorganisasian masyarakat, sistem kerja, pola pemikiran, dan perkembangan sosial. Perubahan sosial dalam teori evolusi jarang menimbulkan konflik karena perubahannya berlangsung lambat dan cenderung tidak disadari.

Menurut Soerjono Soekanto terdapat tiga teori utama dalam evolusi:

- Teori Evolusi Uniliniear.

Teori ini menyatakan bahwa manusia dan masyarakat mengalami perkembangan yang sesuai dengan tahap-tahap tertentu. Perubahan ini membuat masyarakat berkembang dari yang sederhana menjadi tahapan yang lebih kompleks.

- Teori Evolusi UniversL

Teori ini menyatakan bahwa perkembangan masyarakat tidak perlu melalui tahapan tertentu yang tetap karena menurut teori ini kebudayaan manusia telah mengikuti suatu garis evolusi tertentu.

- Teori Evolusi Multilinear

Teori ini menyatakan bahwa perubahan sosial dapat terjadi dalam beberapa cara, tetapi cara tersebut akan mengarah ke arah yang sama, yaitu membentuk masyrakat. yang lebih baik.

\section{Teori Fungsionalis}

Teori Fungsionalis menyatakan bahwa ketidakpuasan masyarakat terhadap keadaan sosial yang sedang berlaku merupakan penyebab utama terjadinya perubahan sosial. Ketidakpuasan ini tidak dirasakan oleh semua anggota masyarakat, sebagian anggota masyarakat tidak menginginkan perubahan.

Tapi, jika lebih banyak yang menginginkan perubahan, biasanya perubahan akan terjadi, tetapi apabila hanya kelompok minoritas dengan kekuatan kecil yang 
menginginkan perubahan, maka perubahan tersebut sulit untuk tercapai.

\section{Teori Konflik}

Teori ini sangat sepesial, teori konflik akan menjelaskan bahwa perubahan sosial terbentuk karena adanya konflik dan ketegangan dalam masyarakat. Konflik ini biasanya berupa pertentangan antar kelas penguasa dengan masyarakat yang tertindas. Hal ini tentu akan mempengaruhi masyarakat dalam kelas yang lebih rendah menginginkan adanya perubahan dengan mengatasnamakan keadilan. Dalam hal ini pula bahwa jika memang perubahan yang dikehendaki berhasil tercapai, maka pada akhirnya masyarakat yang terbentuk akan hidup tanpa pembagian kelas.

\section{Teori Siklus}

Teori siklus menyatakan bahwa perubahan sosial ini bagaikan roda yang sedang berputar, artinya perubahan zamam merupakan sesuatu yang tidak dapat dihindari oleh manusia dan tidak dapat dikendalikan oleh siapapun.

Bagaimanapun seseorang berusahan untuk mencegah terjadinya perubahan sosial mereka tidak akan mampu, karena perubahan sosial sudah seperti sifat alami yang dimiliki setiap lingkungan masyaraka

B. Pertumbuhan Penduduk

Pertumbuhan Penduduk ialah suatu perubahan populasi sewaktu-waktu, dan bisa dihitung sebagai perubahan dalam jumlah individu dalam sebuah populasi memakai "per waktu unit" untuk pengukuran. Sebutan pertumbuhan penduduk merujuk pada semua spesies, tapi selalu mengarah pada manusia, dan sering dipakai secara informal untuk sebutan demografi nilai pertumbuhan penduduk, dan dipakai untuk merujuk pada pertumbuhan penduduk dunia.

Malthus, pemikiran tentang pertumbuhan penduduk hanyalah dimana suatu reproduksi merupakan upaya menggantikan masyarakat atau orang yang telah mati karena jumah kematian yang relative tinggi. Beberapa pandangan tentang kependudukan sebelum teori Malthusian dan ketidakselarasan dalam praktek sebelum dan sesudah masa Malthus.
Ajaran Confusian pada masa Cina Kuno (500 SM) menyebutkan bahwa tingginya pertumbuhan penduduk menjadikan nilai output suatu produksi menjadi berkurang. Ajaran ini juga menyatakan bahwa pemerintah mempunyai tanggung jawab untuk menjaga kestabilan penduduk dan luas lahan (tempat penduduk tinggal dan beraktifitas). Solusinya adalah dengan cara mengadakan migrasi menuju tempat yang lebih sedikit penduduknya.

Plato dan Aristoteles berpendapat bahwa kwalitas manusia dalam memproduksi barang lebih penting dari pada kwantitas masyarakat itu sendiri, terutama dalam memelihara kesejahteraan hidup suatu masyarakat. Jadi penduduk yang berjumlah banyak belum tentu efisien dalam melakukan suatu kegiaatan produksi.

Pada abad ke-17 munculnya Mercantilisme menyebarkan doktrin pronatalis yang memandang pertumbuhan penduduk merupakan hal yang teramat penting karena merupakan instrument peningkatan pendapatan masyarakat. Pronatalis adalah teori yang menyerukan bahwa pendapatan nasional sama dengan seluruh hasil produksi dikurangi upah yang diterima tenaga kerja. Karena upah tenaga kerja pada waktu itu cenderung turun maka angkatan kerja akan naik dan negara yang berpenduduk padat akan mendapatkan keuntungan.

Ide yang lain dating dari William Godwin, dia percaya bahawasanya suplai makanan bisa meningkat drastis dengan adanaya teknologi yang maju. Ia juga menambahkan bahwa hal ini tidak akan menyebabkan overpopulation karena dengan sendirinya masyarakat akan membatasi kelahiran. Sementara kemiskinan dan pengangguran abukanlah disebabkan oleh overpopulation melainkan karena institusi social yang tidak merata.

Pada abad ke-18 Adam Smith dan kaum Physiocratic menyatakan bantahan terhadap doktrin Pronatalis. Kaum pemikir ini berpandangan kependudukan bukanlah masalah yang sangat vital yang mempengaruhi kesejahteraan suatu 
masyarkat, tetapi factor tanah lah yang sangat erat kaitannya dengan tingkat produksi.

C. Kebutuhan

Pada dasarnya, setiap manusia memiliki kebutuhan dasar yang harus dipenuhi agar kehidupan dapat berjalan dengan baik. Adapun teori mengenai kebutuhan dasar manusia yang sangat populer, yaitu hierarki kebutuhan Maslow. Hierarki kebutuhan Maslow diperkenalkan oleh Abraham Maslow, yang merupakan seorang teoretikus dan psikolog, pada tahun 1943. Hierarki ini menunjukkan jika manusia termotivasi untuk memenuhi kebutuhan dasar sebelum memenuhi kebutuhan lain. Lantas, apa saja kebutuhan dasar manusia? Hal ini tentu menggambarkan bahwa ketika manusia atau suatu kelompok sosial teemotivasi untuk memenuhi berbagai aspek kebutuhan, tentu mereka lebih mementingkan kebutuhan mendasar, yakni tempat tinggal, makan dan minum, serta pakaian.

Selain hal di atas, terdapat lima tingkat yang berbeda pada hierarki kebutuhan Maslow, mulai dari yang paling dasar hingga yang sifatnya kompleks. Hierarki Maslow umumnya digambarkan dalam bentuk piramida, di mana tingkat terendah piramida terdiri dari kebutuhan paling dasar, sedangkan kebutuhan yang paling kompleks ada di atas piramida. Setelah kebutuhan pada tingkat yang paling rendah terpenuhi, maka manusia dapat beralih ke tingkat kebutuhan berikutnya. Maslow mempercayai jika kebutuhan serupa dengan naluri dan memainkan peran utama untuk memotivasi perilaku. Berikut lima macam kebutuhan manusia dalam teori Maslow:

\section{- Kebutuhan fisiologis (physiological needs)}

Kebutuhan fisiologis menjadi kebutuhan yang paling dasar untuk dipenuhi karena meliputi hal-hal yang vital bagi kelangsungan hidup. Yang termasuk ke dalam kebutuhan fisiologis, yaitu makan, minum, tidur, dan bernapas. Selain pemenuhan nutrisi, kebutuhan fisiologis juga mencakup pakaian, tempat tinggal, dan kehangatan.

Maslow juga memasukkan reproduksi seksual pada tingkat ini. Jika kebutuhan ini tidak terpenuhi, maka tubuh manusia tidak dapat berfungsi secara optimal. Kebutuhan lain pun menjadi sekunder hingga kebutuhan ini terpenuhi.

- Kebutuhan keamanan dan keselamatan (security and safety needs)

Pada tingkat kedua ini, kebutuhan menjadi sedikit lebih kompleks, di mana kebutuhan akan keamanan dan keselamatan menjadi yang utama. Manusia ingin suatu kontrol dan ketertiban dalam hidupnya.

Beberapa kebutuhan dasar manusia akan keamanan dan keselamatan, yaitu keamanan keuangan, kesehatan dan kebugaran serta keamanan dari kecelakaan dan cedera. Manusia pun akan termotivasi dan melakukan tindakan untuk memenuhi kebutuhan tersebut, misalnya dengan bekerja, menabung, pindah ke lingkungan yang lebih aman, dan lainnya.

- Kebutuhan kasih sayang dan rasa memiliki (love and belongingness needs)

Setelah kedua kebutuhan dasar manusia tersebut terpenuhi, maka munculah kebutuhan akan kasih sayang dan rasa memiliki. Ini berkaitan dengan hal-hal tertentu, seperti persahabatan, keintiman, kepercayaan, penerimaan, serta memberi dan menerima kasih sayang.

Dalam memenuhi kebutuhan ini, manusia akan terlibat dalam pertemanan, hubungan romantis, keluarga, kelompok sosial, dan lainnya. Penting bagi manusia untuk merasa dicintai dan diterima oleh orang lain untuk menghindari berbagai masalah, seperti kesepian, depresi, dan kecemasan.

- Kebutuhan penghargaan (esteem needs)

Pada tingkat keempat ini, manusia memiliki kebutuhan akan penghargaan dan rasa hormat. Setelah ketiga kebutuhan sebelumnya terpenuhi, maka kebutuhan akan harga diri ini memainkan peran yang lebih menonjol untuk memotivasi perilaku manusia.

Maslow membagi tingkat ini menjadi dua kategori, yaitu kebutuhan harga diri ang berkaitan dengan martabat, prestasi, penguasaan, dan kemandirian. Kemudian, kebutuhan rasa hormat dari orang lain yang berkaitan dengan status, atensi, dan reputasi.

Orang yang mampu memenuhi kebutuhan ini cenderung merasa yakin dengan 
kemampuannya sehingga memiliki harga diri yang baik dan mendapat penghormatan dari orang lain. Sementara, jika harga diri dan rasa hormat dari orang lain rendah, maka akan mengembangkan perasaan rendah diri. Kebutuhan aktualisasi diri (selfactualization needs)

Kebutuhan aktualisasi diri berkaitan dengan keinginan untuk mewujudkan dan mengembangkan potensi dan bakat, mencari pertumbuhan diri dan pengalaman, serta untuk menjadi segala sesuatu yang diinginkan.

Lebih lanjut dapat dikatakan bahwa kebutuhan subjek merupakan jenis kebutuhan manusia berdasarkan subjek yang membutuhkannya. Kebutuhan ini tediri atas kebutuhan individu dan kebutuhan kualitatif/bersama.

\section{Kebutuhan Individu}

Kebutuhan ini merupakan macam kebutuhan yang harus dipenuhi oleh individu. Namun, kebutuhan setiap individu akan berbeda-beda. Misal seorang mahasiswa membutuhkan cuku catatan, laptop, pulpen dan lain sebagainya. Sedangkan seorang koki membutuhkan alat-alat masak, bahan-bahan dan lain sebagainya untuk membantu melakukan pekerjaannya.

\section{Kebutuhan Bersama}

Kebutuhan ini harus dipenuhi untuk memenuhi kepentingan bersama dan dilakukan secara bersama-sama. Kebutuhan ini juga dibedakan menjadi kebutuhan bersama yang berwujud dan tidak berwujud. Yang berwujud meliputi jalan, jembatan, angkutan umum dan lainnya. Kebutuhan kelompok yang tidak berwujud misalnya keamanan, ketertiban, kebersihan umum, dan menang dalam pertandingan.

\section{METODE PENELITIAN}

\section{A. Desain Penelitian}

Desain penelitian menanyakan sebuah sikap yang berkepentingan, dan mempunyai gambaran yang jelas tentang bagaimana keterkaitan antara variabel yang ada pada tugas penelitian dan apa yang hendak dilakukan oleh seseorang peneliti dalam mengumpulkan data.
1. Jenis Pendekatan

Dalam penelitian ini digunakan pendekatan kualitatif. Penelitian kualitatif adalah penelitian yang dilakukan dalam situasi yang wajar dan data yang dikumpulkan umumnya bersifat kualitatif. Pendekatan kualitatif lebih berdasar pada filsafat fenomenologis yang mengutamakan penghayatan. Metode kualitatif berusaha memahami dan menafsirkan makna suatu peristiwa interaksi tingkah laku manusia dalam situasi tertentu menurut prespektif peneliti sendiri (Husnaini Usman, 2004 : 81) dengan bahasa yang sederhana. Zuriah (2007:91) mengatakan bahwa pendekatan kualitatif adalah pendekatan penelitian yang lebih banyak menggunakan logica-hipotetikoverifikatif.

2. Jenis Penelitian

Jenis penelitian yang digunakan dalam penelitian ini adalah penelitian dasar atau murni. Jujun S.Suriasumantri (1985) menyatakan bawa penelitian dasar atau murni yaitu penelitian yang bertujuan untunk menemukan pengetahuan baru yang sebelumnya belum pernah diketahui (Sugiono 2007:4). Penelitian dasar untuk mngembangkan teori dan tidak memperhatikan kegunaan yang langsung bersifat praktis.

\section{B. Lokasi Penelitian}

Penelitian ini dilakukan pada Masyarakat Suku Bajo yang ada di Desa Pulau Bungin Kecamatan Alas Kabupaten Subawa Nusa Tenggara Barat. Peneliti memilih lokasi penelitian tersebut karena lokasi tersebut memiliki keunikan tersendiri, yaitu sebuah gumpalan pasir yang muncul di permukaan laut yang pada pada akhirnya menjadi sebuah pulau kecil yang dihuni oleh kelompok masyarakat nelayan yang berasal dari Suku Bajo Sulawesi Selatan. Selain itu, lokasi ini berada di di tengah laut dan sangat terpencil, namun warga masyarakat setempat memiliki kemampuan dalam bersaing dan berproses dalam mengembangkan diri dari berbagai aspek kehidupan sosial. Di sisi lain, warga masyarakat yang ada di wilayah ini sangat bersahaja dan mereka hanya mengandalkan sumber penghidupan dari rahim laut, yaitu bekeja sebagai nelayan. 


\section{Subyek Penelitian}

Peneliti dalam penelitian ini merupakan instrument kunci yang memiliki peran yang sangat utama dalam keseluruhan proses penelitian karena setelah memperoleh data, peniliti tidak langsumg menyajikan data dalam laporan, melainkan peneliti harus mengkonfirmasikan dahulu dengan sumber informan untuk mendapat data yang benar dan akurat. Adapun sumber data dalam penelitian ini adalah subyek dimana data ini diperoleh (Arikunto,2002:106). Subyek dalam penelitian ini adalah proses pengembangan masyarakat Suku Bajo yang ada di Desa Pulau Bungin Kecamatan Alas Kabupaten Sumbawa.

D. Jenis Data dan Sumber Data

a. Data primer, yaitu data yang diperoleh melalui obsrvasi dan wawancara langsung di tempat kejadian dan tanya jawab terhadap warga setempat tentang proses perluasan wilayah, pertumbuhan penduduk, dan proses pengembangan masyarakat dalam berbagai aspek kehidupan sosial yang tejadi pada Suku Bajo yang ada di Desa Pulau Bungin Kecamatan Alas Kabupaten Subawa.

b. Data sekunder adalah data yang diperoleh melalui dokumentasi, yang merupakan data sekunder adalah data yang diperoleh dari kantor desa ataupun dari instansi lain yang terkait dengan objek yang akan diteliti yakni proses perluasan wilayah, pertumbuhan penduduk, dan proses pengembangan masyarakat dalam berbagai aspek kehidupan sosial yang ada di Desa Pulau Bungin Kecamatan Alas Kabupaten Sumbawa.

E. Tehnik Pengumpulan Data

1. Data Primer

Data primer adalah data yang diperoleh dan dikumpulkan secara langsung dari sumber-sumber asli, dalam hal ini pemerintah desa dan seluruh warga masyarakat yang dapat memberikan data yang dibutuhkan peneliti yang sesuai masalah dalam penelitian. Cara pengumpulan sebagai berikut.

a. Wawancara

Wawancara adalah mencari informasi tentang suatu hal dengan mengajukan pertanyaan (narasumber) secara detail. Wawancara digunakan sebagai tekhnik pengumpulan data apabila peneliti ingin mendapatkan dan mengetahui hal-hal dari informan secara lebih mendalam dan jumlah informan sedikit.

b. Observasi

Observasi adalah suatu proses yang kompleks, yaitu suatu proses yang tersusun dari berbagai proses biologis dan psikologis. Dua diantaranya yang terpenting adalah proses-proses dan ingatan. Dari segi proses pelaksanaan pengumpulan data, observasi dapat dibedakan menjadi dua yaitu observasi dan non partisipasi observasi, selanjutnya dari segi instrumentasi yang digunakan maka observasi dibedakan menjadi observasi terstruktur dan tidak struktur.

Nasution (2003:106) menjelaskan bahwa observasi adalah kegiatan yang dilakukan untuk memperoleh informasi tentang kelakuan manusia seperti terjadi dalam kenyataan. Jadi dapat disimpulkan bahwa metode observasi diartikan sebagai pengamatan dan pencatatan secara sistematis terhadap gejala yang nampak pada objek penelitian.

c. Dokumentasi

Menurut Moleong (:161) bahwa dokumentasi adalah setiap pertanyaan tertulis yang disusun oleh seseorang atau lembaga untuk keperluan pengujian peristiwa atau akunting. Jadi dapat disimpulkan bahawa metode dokumentasi adalah suatu tehnik pengumpulan data yang digunakan sebagai acuan dalam mencari dan referensi yang berkenaan langsung dengan masalah dalam penelitian. Adapun yang dijadikan data penunjang dalam penelitian ini adalah berupa buku-buku, catatan atau jenis dokumentasi tertulis lainya, seperti profil desa, foto-foto, dan catatan atau agenda yang dibuat oleh tokoh yang ada di desa. 
2. Data Sekunder

Data sekunder adalah data yang dikumpulkan oleh lembaga-lembaga yagn terkait dan dipublikasikan berupa bacaan atau literatur yang berkaitan dengan penelitian ini. Pengumpulan data sekunder salah satunya studi perpustakaan.

F. Uji Keabsahan Data

Untuk menetapkan keabsahan data diperlukan tehnik pemeriksaan. Menurut Moleong (2002:173) ada empat kriteria yang digunakan untuk memeriksa keabsahan data, yaitu derajat kepercayaan, keteralihan, kebergantungan, dan kepastian. Berdasarkan penjelasan tersebut maka dalam penelitian ini penelitis menggunakan tehnik keabsahan data yang sesuai dengan kriteria yang telah disebutkan di atas dimana peneliti memperhatikan tingkat kepercayaan data, kepastian data, ketergantungan antara data yang satu dengan data yang lainya, dan kepastian data yang telah terkumpul.

Dalam penelitian ini, data yang dikumpulkan adalah data-data yang bersifat alamiah dimana data-data yang terkumpul lebih banyak didapatkan dari informan yang kadang-kadang memiliki keterbatasan karena disebabkan oleh keletihan atau keterbatasan mengingat dapat menyebabkan kekeliruan, sehingga peneliti perlu memperhatikan keteralihan dan kebergantungan yang juga sering disebut dengan validitas dan reliabilitas data. Selain itu perlu juga diperhatikan kepastian objektivitas (sumber) dimana dalam hal ini peneliti melakukan seleksi terhadap data-data yang telah diberikan oleh nara sumber dan tidak tergantung kepada pandangan atau persetujuan seseorang serta berusaha mencari keterangan dari nara sumber yang jujur, faktual, dan dapat dipastikan keteranganya.

Setelah data terkumpul dan sudah diuji keabsahannya maka data-data tersebut perlu diorganisasikan, diseleksi, dan kemudian disusun dalam bentuk tulisan. Meskipun datanya cukup variatif namun dengan dilakukanya dengan pengecekan keabsahan data dengan kriteria-kriteria yang telah ditetapkan sebelumnya maka data yang diperoleh betul vailid dan akurat. Dalam penelitian ini data-data yang telah diperoleh dilapangan nanti akan dibanding-bandingkan kemudian dianalisis untuk menarik generalisasi atau kesimpulan.

G. Tehnik Analisis Data

Analisis data dalam penelitian merupakan sesuatu kegiatan yang sangat penting dan memerlukan ketelitian serta kekritisan dari penulis.

Dari pengertian di atas, maka untuk mnganalisis hasil penelitian dalam laporan ini menggunakan analisis induktif. Pendekatan induktif adalah suatu analisis data yang memungkinkan temuan-temuan penelitian muncul dari keadaan umum, tema-tema dominan dan signifikan yang ada dalam data tanpa menagabaikan hal-hal yang muncul oleh struktur bioligisnya. Jadi metode ini sangat tepat bila digunakan untuk menganalisis data yang dimulai dengan gejala-gejala yang sifatnya umum kemudian diuraiakan menjadi kesimpulan yang sifatnya khusus.

\section{HASIL PENELITIAN DAN PEMBAHASAN}

A. Proses Perluasan Wilayah Dan Pertumbuhan Penduduk Suku Bajo Di Desa Pulau Bungin Kecamatan Alas Kabupaten Sumbawa

Pulau Bungin merupakan sebuah pulau kecil yang terletak di Pulau Sumbawa. Pulau kecil ini merupakan salah satu desa pulau yang terletak di Kecamatan Alas Kabupaten Sumbawa Nusa Tenggara Barat. Jumlah penduduk yang menetap di pulau ini sangat padat dan tidak seimbang dengan luas wilayah hunian sehingga dijuluki sebagai pulau yang penduduknya terpadat di dunia. Namun mayoritas penduduk di pulau ini berasal dari keturunan Suku Bugis Sulawesi Selatan sehingga corak hidup yang berkembang di pulau ini ada kemiripan dengan pola kebiasaan yang ada pada masyarakat Bugis Sulawesi Selatan. Dalam kesehariannnya, merekapun menggunakan bahasa bajo atau bahasa bugis, sementara pola bertahan hidup yaitu bersumber dari rahim laut. Meskipun dengan jumlah penduduk yang sangat padat, namun warga masyarakat yang tinggal di pulau ini mampu mengembangkan diri dari berbagai aspek kehidupan sosial, 
termasuk aspek pendidikan, perekonomian, dan keagamaan, dan lain-lain.

Terkait dengan hal di atas, warga setempat yang ada di Pulau Bungin mengakui bahwa dahulu Pulau Bungin hanya merupakan hamparan atau gundukan pasir yang muncul di atas permukaan laut. Hamparan pasir yang berupa daratan tersebut tersebut hanya memiliki ukuran luas yang hanya dapat ditempati oleh dua bangunan rumah panggung. Dari hasil wawancara menyatakan bahwa hamparan pasir tersebut ditemukan oleh seorang pelaut bugis dari Sulawesi Selatan, yang pada akhirnya mendirikan sebuah mushollah atau masjid kecil dan satu unit rumah panggung khas Sulawesi Selatan.

Lambat-laun, dari waktu ke waktu, hamparan pasir yang ada di Pulau Bungin mengalami perluasan. Warga masyarakat Bungin yang berketurunan Suku Bajo mengatakan bahwa pulau ini mengalami perluasan wilayah karena disebabkan oleh adanya kebutuhan beberapa nelayan yang ingin bertempat tinggal di kawasan tersebut, sebab tempat tersebut sangat strategis untuk melancarkan aktifitas kerja sebagai nelayan. Maslow, yang merupakan seorang teoretikus dan psikolog menunjukkan bahwa jika manusia termotivasi untuk memenuhi kebutuhan sebelum memenuhi kebutuhan lain, lantas apa saja kebutuhan dasar manusia? Hal ini tentu menggambarkan bahwa beberapa nelayan yang ingin memenuhi kebutuhan akan penghasilan atau kebutuhan dasar untuk memenuhi kebutuhan sehari-hari bagi keluaraga sehingga untuk melancarkan aktifitas kerja mereka di laut, mereka pun harus bertempat tinggal di dekat tempat kerja mereka sehingga pada akhirnya pulau kecil ini menjadi kebutuhan dasar mereka akan tempat tinggal yang sangat strategis.

Selain itu, RG Squad mengatakan bahwa secara sadar dimana manusia akan memanfaatkan lingkungan dalam usaha memenuhi kebutuhan hidupnya. Dengan adanya pembangunan, kehidupan dan kesejahteraan manusia dapat meningkat. Hal inilah yang mendasari bahwa dalam memenuhi salah satu kebutuhan hidup manusia, yaitu khususnya untuk kebutuhan tempat tinggal, Suku Bajo yang ada di desa pulau ini membiasakan diri dalam memanfaatkan sumber daya alam yang ada di sekitarnya, dalam hal ini adalah tradisi mengumpulkan batu karang untuk membuat tempat tumpuan dari sebuah rumah panggung di tepi laut.

Proses mengumpulkan batu karang untuk dijadikan sebagai bahan timbunan di tepi laut dan sebagai tempat berdirinya bangunan rumah panggung khas Sulawesi Selatan telah menjadi suatu tradisi bagi warga masyarakat yang ada di Desa Pulau Bungin. Tradisi inipun akhirnya menjadi suatu kewajiban bagi calon pengatin yang ada di Desa Pulau Bungin. Hal ini tentu sudah merupakan suatu proses sehigga pulau kecil ini mengalami pengembangan atau perluasan wilayah.

Berangkat dari hasil wawancara dan pengamatan yang ada bahwa bertahannya tradisi pengumpulan batu karang tentu pula akan berdampak pada pertumbuhan penduduk yang ada di desa pulau ini. Akibat dari pertumbuhan penduduk itu sendiri tentu akan mempengaruhi kembali perluasan wilayah yang ada di pulau kecil ini sehingga tidaklah mengherankan jikalau seiring dengan laju pertumbuhan penduduk yang ada di Desa Pulau Bungin, seiring pula dengan geliat penduduk dalam mengembangkan atau memperluas wilayah mereka dengan tetap berpegang teguh pada suatu tardisi, yaitu "Tradisi Mengumpulkan Batu Karang".

RG Squad, pengembangan wilayah merupakan salah satu cara untuk mencapai keberhasilan pelaksanaan pembangunan. Keberhasilan pembangunan untuk masyarakat bukanlah hanya dilihat dari satu aspek saja, melainkan beberapa sektor yang harus telibat demi untuk mengembangkan wilayah atau kelompok masyarakat. Terkait dengan hal ini, laju pertumbuhan penduduk dan perluasan wilayah yang ada di Desa Pulau Bungin tentu merupakan pula suatu tantangan bagi warga setempat dalam mengembangkan diri di berbagai sektor. Selain itu, Korten (2001:110) dalam "People centered development" mengatakan bahwa pada hakikatnya semua pembangunan dilaksanakan untuk meningkatkan kesejahteraan 
masyarakat. Untuk itu pembangunan terhadap masyarakat desa dipusatkan pada mereka. Hal inilah yang menjadi kekuatan bagi warga masyarakat Desa Pulau Bungin sehingga mampu berproses mengalami suatu perubahan sosial atau perekembangan di berbagai sektor kehidupan masyarakat.

Dari pengamatan yang ada, demikian juga dari data statistik yang ada di Kantor Desa Pulau Bungin bahwa seiring dengan pertumbuhan penduduk dan kebutuhan akan tempat tinggal bagi penduduk yang ada di pulau kecil ini, Desa Pulau Bungin sudah mencapai sekitar 8,5 (delapan koma lima) hektar. Kadir (59 th) yang selaku warga setempat mengakui bahwa faktor utama yang menyebabkan perluasan wilayah Pulau Bungin adalah bertahannya tradisi mengumpulkan batu karang dari laut. Demikian juga dari Sofyan (60 th) selaku mantan Kepala Desa Pulau Bungin mengatakan,“" Tradisi mengumpulkan batu karang dari laut merupakan suatu tradisi yang diwajibkan kepada warga penduduk yang ingin melangsungkan pernikahan dan ada niat untuk menetap di Pulau Bungin, dan setelah melangsungkan pernikahan barulah kemudian mendirikan rumah panggung khas Sulawesi Selatan". Perlu juga dipahami bahwa bentuk bangunan rumah yang dibangun di pulau ini adalah mengikuti bentuk rumah adat khas bugis Sulawesi Selatan yang dibawah dari nenek moyang mereka, yaitu dari Sulawesi Selatan, dan juga menyesuaikan dengan kondisi dan letak geografis dari pulau tersebut.

Seiring dengan perkembangan zaman, jumlah penduduk di Pulau Bungin semakin mengalami peningkatan kuantitas. Sofyan menyampaikan bahwa jumlah penduduk yang ada di wilayah Pulau Bungin sudah mencapai kurang lebih dari 4.000 (empat ribu) jiwa, berarti suatu gambaran bahwa tidak adanya keseimbangan antara jumlah penduduk dengan lokasi pemukiman di pulau ini. Namun mereka tetap mampu bertahan hidup dengan layak, bahkan mampu mengikuti arus informasi dan perkembangan teknologi.

Di sisi lain, suatu hal yang paling menguntungkan bagi penduduk yang ada di Desa Pulau Bungin yaitu ketika terbangunnya infrastruktur jalan lintas darat di atas laut, mereka mampu menjalin hubungan komunikasi dengan pihak luar dalam berbagai bidang sehingga mampu berdaya saing terhadap peningkatan ekonomi. Selain itu, rahim laut adalah sumber utama pada mata pencaharian mereka yang justru ditumbuhkembangkan dengan menggunakan fasilitas teknologi modern, baik dalam hal peralatan penangkapan ikan maupun dalam sistem pemasaran. Hal ini pula yang membuat mereka untuk tetap bertahan hidup di desa pulau yang unik dan terpencill ini, bahkan mereka mampu meningkatkan perekonomian mereka.

Adam Smith menyatakan bahwasanya ada hubungan harmonis antara perekonomian dengan pertumbuhan penduduk. Dalam hal ini, tidaklah mengherankan jikalau di Desa Pulau Bungin, yang mana walaupun wilayahnya sangat kecil, akan tetapi mereka mampu bersaing dan berproses dan berpenghidupan dengan mengandalkan hasil pekerjaan mereka dari rahim laut sehingga mempengaruhi terjadinya proses biologis atau melangsungkan pernikahan hingga memiliki keturunan, yang tentu pula dapat mempengaruhi laju pertumbuhan penduduk.

Di sisi lain, Adam Smith lebih lanjut bahwa pertumbuhan penduduk dipengaruhi oleh permintaan tenaga kerja dan permintaan tenaga kerja dipengaruhi oleh produktifitas suatu lahan. Terkait dengan ini yang mana Pulau Bungin memiliki rahim laut yang cukup produktif untuk dikelola, dan ini mempengaruhi penduduk setempat untuk bertahan hidup di di desa terpencil ini dengan mengandalkan rahim laut sebagai sumber mata pencaharian mereka. Beberapa informasi dari warga masyarakat bahwa selain penduduk asli dari Pulau Bungin, sebagian juga dari pihak luar untuk meluangkan diri mencari nafkah di Desa Pulau Bungin. Namun dengan adanya penghasilan atau perekonomian yang mapan dari rahim laut, mereka melangsungkan pernikahan di desa pulau ini hingga memiliki keturunan, yang sudah barang tentu mempengaruhi laju pertumbuhan penduduk di Pulau Bungin, dan tentu pula mempengaruhi kekuatan tradisi pengumpulan batu karang dari laut sehingga 
pada bagian tepi laut selalu mengalami perluasan daratan.

Hal di atas disampaikan juga oleh Munandar (28 th) yaitu salah seorang warga masyarakat Desa Pulau Bungin bahwa kepadatan penduduk yang ada di Pulau Bungin disebabkan oleh maraknya kawinmawin antara warga penduduk Pulau Bungin dengan penduduk luar. Rata- rata penduduk luar yang menikah dengan warga Pulau Bungin, entah itu pria atau wanita memiliki niat untuk menetap di pulau ini dengan suatu alasan bahwa tinggal di Pulau Bungin adalah memudahkan untuk bertahan hidup, sebab di sekitar Pulau Bungin memiliki kekayaan alam laut yang sudah semenjak dulu menjadi sumber mata pencaharian. Mereka pun juga beranggapan bahwa tinggal di Pulau Bungin berarti dekat dengan lokasi pencarian nafkah yaitu di laut atau bekerja sebagai nelayan.

Di sisi lain, Sofyan selaku mantan Kepala Desa Pulau Bungin, yang tentu banyak memahami kondisi warga masyarakat setempat menuturkan bahwa pada sekitar tahun 2002, luas Pulau Bungin sebesar 6,5 hektar dengan jumlah penduduk hanya 2.700 jiwa. Namun berdasarkan pendataan ulang pada tahun 2007, luas pulau ini mencapai 8,5 hektar dengan jumlah penduduk 3.126 jiwa. Hal ini tentu disebabkan oleh pertambahan penduduk dari luar dengan melalui proses perkawinan, dan tentu pula dipengaruhi oleh tingkat kelahiran bayi.

Selain itu, Baim yang juga salah seorang warga masyarakat Bungin bertutur bahwa walaupun penduduk Pulau Bungin tergolong padat, namun tetap saja ada yang merantau. Misalnya merantau ke luar Irian Jaya, Bali, Maluku, dan Belitung. Akan tetapi, walaupun mereka merantau, namun suatu saat akan kembali lagi ke Pulau Bungin, bahkan akan kembali bekerja sebagai nelayan bersama sanak keluarga yang datang dari tempat merantau. Hal ini tentu menjadi sewajarnya jikalau Pulau Bungin memiliki penduduk yang kepadatan penduduknya tidak seimbang dengan luas hunian wilayah.

Dari uraian di atas dapat disimpulkan bahwa proses pengembangan wiayah yang ada di Desa Pulau Bungin Kecamatan Alas Kabupaten Sumbawa yaitu diwali dengan ditemukannya gundukan pasir di atas permukaan laut, yang kemudian dihuni oleh seorang pelaut asal Bugis Selatan. Pelaut bugis Sulawesi Selatan tersebut mendirikan sebuah rumah panggung dan sebuah mushollah atau masjid kecil yang berukuran kecil, dan beberapa nelayan yang sering mendatangi tempat tersebut, yang pada akhirnya ada keinginan untuk betempat tinggal di kawasan tersebut dengan cara mengumpulkan batu karang yang lalu ditimbun di tepi pantai yang mana sebagai tempat pijakan untuk membangun sebuah rumah panggung.

Suatu alasan yang mendasari beberapa nelayan untuk bertempat tinggal di kawasan pulau kecil itu yaitu pertama karena mereka ingin dekat dengan tempat kerja mereka yaitu bekeja sebagai nelayan. Kedua adalah bahwa ketika salah seorang warga penduduk yang akan melangsungkan suatu pernikahan, mereka diwajibkan untuk mengumpulkan batu karang dengan tujuan untuk melakukan penimbunan di tepi pantai atau tepi laut yang mana akan sebagai tempat untuk berdirinya sebuah rumah panggung, yang tentu pula akan membina keluarga yang baru. Selain itu, setelah terjadinya kawin-mawin, yang mana tentu akan menyebabkan terjadinya laju pertumbhanenduduk, dan tentu akan berpengaruhi lagi pada suatu kebutuhan dasar berupa papan atau tempat tinggal. Karena tidak adanya lahan untuk membangun rumah baru di desa kecil ini, tepaksa akan kembali pada tradisi pengumpulan batu karang dari laut sehingga pulau ini selalu mengalami perluasan wilayah atau lahan. Selain itu, bahwa dengan berbondong-bondongnya pihak luar untuk hijarah atau menetap di desa kecil ini untuk mencari penghidupan dari rahim laut, dan mereka pun juga diberikan kesempatan untuk menetap di desa ini dengan melalui suatu perkawinan dengan penduduk asli (penduduk menetap) di pulau ini, tentu juga akan berdampak pada pertumbuhan penduduk dan berujung pada perluasan wilayah pada desa terpencil ini. .

B. Proses Pengembangan Masyarakat Suku Bajo Di Desa Pulau Bungin

Pulau Bungin Bungin adalah suatu pulau kecil yang memiliki suatu keuinikan. 
Salah satu keunikan yang mengangkat nama pulau ini di kalangan wisata yaitu sebuah tradisi untuk mengumpulakan batu karang dari laut. Bentuk tradisi tersebut sangat dihargai oleh warga setempat sehingga berlangsung secara generasi, bahkan hingga sampai saat ini masih sangat dipertahankan.

Tradisi mengumpulkan batu karang dari laut berlangsung disaat seseorang warga penduduk yang akan membangun sebuah rumah tangga atau melangsungkan pernikahan, yang mana pada pihak laki-laki diwajibkan untuk mengumpulkan sejumlah batu karang dari laut, baik itu pihak laki-laki berasal dari Pulau Bngin sendiri maupun berasal dari pihak luar pulau. Kumpulan dari batu karang tersebut akan dijadikan sebagai bahan timbunan di tepi laut, dan timbunan tersebut akan menjadi tempat didirikannya sebuah rumah panggung, dan menjadi tempat tinggal mereka kelak dalam membina rumah tangga yang baru.

Terkait dengan hal di atas, beberapa warga setempat yang ada di Desa Pulau Bungin Kecamatan Alas Kabupaten Sumbawa menyampaikan bahwa suatu alasan bahwa lokasi atau lahan untuk membangun rumah di Pulau Bungin sama sekali tidak ada, akhirnya bagi warga penduduk yang akan membangun rumah baru terpaksa harus memperluas wilayah pulau ini yaitu menggunakan tepi laut dengan catatan menimbunnya dengan batu karang yang diambil atau dikumpulkan dari dalam laut.

Proses perluasan wilayah dengan proses pengembangan masyarakat Suku Bajo yang ada di Desa Puau Bungin tampak signifikan. Dari pengamatan dan hasil wawancara bahwa dengan terjadinya perluasan wilayah yang selain dipicu oleh keinginan beberapa nelayan Suku Bajo Sulawesi Selatan yang ingin bertempat tinggal di pulau kecil ini, adalah juga karena laju pertumbuhan penduduk sehingga terjadi tradisi pengumpulan batu karang dari laut. Namun dari pertumbuhan penduduk tersebut tentu mempengaruhi warga setempat untuk mengebangkan aktifitas sosial mereka sendiri. Hanya saja mereka merasa sangat terkendala oleh faktor interaksi sosial dengan desa-desa lain yang ada di Kecamatan Alas. Hal ini disebabkan karena Desa Pulau Bungin pada awalnya berada di tengah laut, dan untuk berkunjung dan atau keluar dari pulau kecil ini yaitu harus menggunakan alat transportasi laut berupa perahu atau sampan. Namun, stabilitas ombak tidaklah selamanya akan bersahabat sehingga untuk memenuhi berbagai kebutuhan masyarakat yang ada di desa pulau ini tidaklah dengan begitu muda. Tentu dalam hal ini juga merupakan suatu tantangan bagi warga setempat dalam membangun wilayah mereka.

Dalam mencapai pembangunan wilayah atau pengembangan wilayah di sutu desa seperti di Desa Pulau Bungin, tentu tentu tidak akan mungkin tercapai jikalau warga kelompok masyarakat tidak mimiliki solidaritas yang tinggi untuk membangun wilayahnya sendiri. Durkheim melihat bahwa pengembangan masyarakat atau perubahan sosial akan cepat terjadi jikalau perubahan masyarakat dari solidaritas mekanik menuju solidaritas organik, yang ditandai dengan adanya pembagian kerja. Selain itu, solidaritas mekanik ditandai dengan kondisi masyarakat yang masih sederhana, pembagian kerja sederhana, dan masih bersifat kekeluargaan.

Berdasarkan solidaritas mekanik yang ditandai dengan kondisi masyarakat yang masih sederhana, pembagian kerja sederhana, dan masih bersifat kekeluargaan sehingga sebuah kelompok sosial mampu mengalami perubahan sosial secara progressif, Desa Pulau Bungin pun telah berproses dalam mengembangkan diri atau membangun wilayahnya, baik secara fisik maupun secara non fisik. Mereka pun saling bekerja sama utuk membangun wilayah mereka dengan didasari rasa solidaritasyang tinggi, azas kekeluargaan, pembagian kerja, bahkan terjadi secara swasembada masyarakat atau secara sukarela.

Tekait dengan hal tersebut, Sofyan (60 tahun) seorang warga Desa Pulau Bungin, yang juga selaku mantan Kepala Desa Pulau Bungin bertutur bahwa dahulu yaitu sebelum tahun 2000, yang mana ketika orang-orang akan berkunjung ke Pulau Bungin harus menyeberang di atas laut dari daratan Alas dengan menggunakan perahu sampan. Beda 
dengan sekarang, para pengunjug tidak perlu lagi menggunakan perahu sampan. Mereka dapat menikmati perjalanan dengan melewati jalan darat yang melintas di atas laut (infrasrtruktur jalan) hingga menemukan Pulau Bungin. Jalan yang melintas di atas laut tersebut adalah berkat usaha kerjasama dan perjuangan masyarakat Pulau Bungin sendiri yang didasari oleh rasa kekeluargaan yang tinggi, solidaritas sehingga penduduk yang ada di pulau ini banyak mengalami perubahan sosial, khususnya perubahan sosial di sektor ekonomi dan di sektor pendidikan.

Sofyan bertutur bahwa ketika belum terbangunnya jalan darat yang melintas di atas laut, tingkat pendidikan di Pulau Bungin masih sangat rendah. Hal ini disebabkan oleh alat transportasi laut yag kurang menjamin. "Terkadang jika ombak laut lagi naik, sampan-sampan yang biasanya mengantar jemput anak-anak sekolah ke desa seberang yaitu ke Alas mengalami keterlambatan. Sementara pada saat itu, pihak sekolah memiliki peraturan yang ketat bahwa jika seorang siswa yang sering terlambat berarti akan dikeluarkan dari sekolah. Selain itu, dalam kondisi cuaca buruk, terkadang anakanak sekolah terlambat pulang ke rumahnya, yaitu ke Pulau Bungin. Mereka terkadang pulang pada waktu malam, sehingga para orang tua siswa kuatir akan keberadaan anaknya di tengah jalan. Hal inilah yang merupakan suatu faktor sehingga terjadinya putus sekolah," ujar Sofyan mengenang kondisi pendidikan anak sekolah di Desa Pulau Bungin, yaitu disaat belum terbangunnya infrastruktur jalan yang menghubungkan daratan Alas Sumbawa dengan Pulau Bungin.

Pada tahun 2000, ketika Pulau Bungin dihubungkan oleh sebuah lintasan jalan darat yang membentang di atas laut dengan Alas Sunbawa, kondisi masyarakat yang ada di desa nelayan ini mangalami perkembangan dalam hal pendidikan. Beberapa sekolah telah terbangun, yakni satu PAUD, satu TK, dua SD, dan satu SMP. Akan tetapi, untuk tingkat SLTA, anak-anak yang ada di desa pulau ini harus melanjutkan jenjang pendidikan mereka ke desa seberang, namun mereka tetap bolak- balik dari rumah mereka dengan melewati jalan lintas darat yang terbentang di atas laut.

Baim (50 th) yang juga selaku warga setempat Pulau Bungin menyampaikan bahwa dampak lain yang dirasakan oleh warga masyarakat Pulau Bungin di saat terbangunnya infrastruktur jalan yang melintas di atas laut adalah kebutuhan akan sarana yang bersentuhan langsung dengan aktifitas keseharian mereka. Pemenuhan komsumsi air bersih telah dirasakan oleh setiap warga setempat, pengadaan listrik masuk desa telah terwujud dengan memanfaatkan sepanjang lintas jalan darat di atas laut sebagai tempat untuk mematok tiang-tiang listrik.

Selain itu, Abdul Samad (28 th) selaku warga setempat bertutur bahwa sebagai desa nelayan, para nelayan Bungin mengalami sistem pemasaran pada hasil tangkapan mereka. "Dulu nelayan-nelayan yang ada di pulau ini harus menunggu perahu juragam ikan dari luar, ataupun mereka yang langsung membawa di tempat pelelangan ikan terdekat. Tapi setelah adanya infrastruktur jalan yang melintas di atas laut, kebanyakan nelayan hanya menunggu kedatangan mobil untuk menyerahkan hasil tangkapan ikan mereka yang lalu kemudian di bawa ke berbagai pasar atau di warung makan. Namun tetap saja masih ada sebagian nelayan yang menggunakan perahu untuk mengantar hasil tangkapan ikan mereka di berbagai tempat tujuan."

Dalam pengembangannya yaitu setelah munculnya jalan lintas darat di atas laut, pola interaksi masyarakat yang ada di Pulau Bungin bukan hanya terwujud dalam hal perikanan laut. Ragam jenis usaha ekomi masyarakat perlahan muncul, seperti bangunan toko untuk pemenuhan kebutuhan sehari-hari dari masyarakat setempat, usaha jasah intenet, rumah makan, demikian juga dengan keleluasan pedagang keliling dari luar untuk mencari rezeki di pulau ini.

Dari gambaran di atas dapat pula dikatakan bahwa proses pengembangan Desa Pulau Bungin tentu tidak akan mencapai suatu hasil jikalau tidak melalui suatu gerakan yang dinamakan pengembangan masyarakat (community development) sebagaimana 
rumusan konsep Brokensha dan Hodge dalam Adi (2003:200) bahwa pengembangan masyarakat adalah suatu gerakan yang dirancang guna meningkatkan taraf hidup keseluruhan masyarakat melalui partisipasi aktif dan inisiatif dari masyarakat. Dalam hal ini, ini yang mana Munandar (28 th) yang selaku warga setempat mengatakan bahwa warga masyarakat Suku Bajo yang ada di Desa Pulau Bungin mampu menjawab suatu tantangan untuk melakukan suatu perubahan sosial secara progressif yaitu dengan melalui sistem pembagian kerja, rasa solidaritas yang tinggi atau kekeluargaan, dan saling bahumembahu.

Terkait dengan hal di atas, Baim yang selaku warga setemat menyampaikan, "Pada saat berlangsungnya pembangunan jalan darat diatas laut, warga di sini saling membahu dan saling membantu. Mereka pun saling mengeluarkan uang demi untuk tercapainya tujuan dari desa ini yaitu berhasinya jalanan darat yang membentang di atas laut." Ungap Baim.

Demikian juga Abdul Samad mengatakan bahwa, "Proses pembangunan jalanan darat di atas laut yang mana memakan waktu cuku lama itu tidak mungkin akan tercapa tanpa ada kesadaran dan partisipasi warga setempat." Begitu pula Sofyan yang selaku mantan Keala Desa Pulau menyanmpaikan bahwa "Atas dasar pembagian kerja dan yang didasari rasa keelurgaan, di mana pembangunan jalan darat di pulau ini, yang sebagai salah satu tombak untuk mengembankan pulau ini. Dan Alhamdulillah dengan terwujudnya pembangunan jalan tersebut, sector-sektor lain pun tuut terbangun, seperti sector pendidikan, perdagangan, pemenuhan kebutuhan iar bersih, bahkan Listrik jugasudah masuk. Pokoknya banyak aktfitas bisnis yang bekembang setelah adanya interaksi dengan desa-desa lain, dan itu berkat adanya bentuk kekerjasamaan dari kami yaitu dengan membuat jembatan atau jalanan darat yang dapat dilalui oleh warga luar dan warga setempat."uncap Sofyan.

Dari pengamatan yang ada, bahwa warga masyarakat Desa Pulau Bungin adalah warga masyarakat yang berketutunan Suku
Bajo, yang mana memiliki sifat kekeluargaan dan rasa solidaritas yang tinggi. Selain itu mereka pun memiliki bentuk pekerjaan yang sama yaitu sebagai nelayan. Idrus Abustam mengatakan bahwa pada suatu kelmpok sosial atau masyarakat, yang mana ketika memiliki profesi atau jendi pekerjaan yang sama akan memngkinkan untuk terciptanya rasa solidaritas yang tinggi. Idrus Abustamtam juga mengatakan bahwa pada kelompok sosial yang emiliki jenis etnis yang sama akan memudahkan untuk tercapainya suatu sifat kekerjasamaan yang tinggi. Dalam hal ini, warga masyarakat Suku Bajo yang ada di Desa Pulau Bungin Kecamatan Alas Kabupaten Sumbawa yang mana memiliki sumber mata pencaharian yang sama yaitu dari rahim laut atau bekerja sebagai nelayan, berarti mereka memiliki profesi atau jenis pekerjaan yang sama. Adanya jenis pekerjaan yang sama yang mana tentu akan memudahkan untuk terciptanya rasa persaudaraan atau bentuk kekerjasamaan yang tinggi. Hal ini dibuktikan yang mana ketika warga masyarakat Suku Bajo di Desa Pulau Bungin Kecamatan Alas Kabupaten Sumbawa saling bahu-membahu dalam mengebangkan wilayah mereka, baik dengan terbangunnya infrastruktur jalan darat di atas laut, maupun dengan bentuk kekerjasamaan yang lain dalam meningkatkan perekonomian mereka, ataupun dalam bentuk perikanan, keagamaan, politik, dalan lain-lain.

Terlepas dari kesanggupan warga masyarakat Suku Bajo yang ada di Desa Pulau Bungin Kecamatan Alas Kabupaten Sumbawa dalam mengembangkan diri di sektor pendidikan dan perekonomian, desa pulau ini juga menyimpan suatu keunikan tersendiri. Keunikan pulau ini tampak pada hewan piaraan, yaitu ditemukannya komunitas hewan piaraan berupa kambing yang bertahan hidup walaupun tidak ada tumbuh-tumbuhan sebagai sumber makanannya. Hewan piaraan di pulau ini hanya mengkomsumsi berbagai jenis sampah, seperti kertas atau kain yang tergeletak di berbagai sudut-sudut jalan. Selain itu, prilaku kambing di pulau ini sungguh meresanhkan pada warga sekitar, sebab apabila kambingkambing tersebut menemukan kardus di 
dalam kios atau jemuran pakaian, mereka pun langsung menyolongnya. Namuan kesemuanya ini memberi keuntungan bagi warga masyarakat Pulau Bungin sebab dengan keunikan yang tersimpan di pulau ini tentu mampu mempengaruhi orang luar untuk berkunjung. Berkat kunjungan orang-orang luar tersebut dengan melewati jalan lintas di atas laut, yang mana tentu pula dapat mengenal keunikan atau sisi kehidupan masyarakat Pulau Bungin sehingga menjadi media pada orang-orang lain, bahkan dapat memberi pemasukan devisa kepada masyarakat setempat, entah itu dengan menikmati makanan khas yang ada di Pulau Bungin, atau berbelanja di sebuah warung, atau pun dengan membeli oleh-oleh khas yang disediakan oleh warga masyarakat setempat.

Dari uraian di atas dapat disimpulkan bahwa proses terjadinya pegembangan pada masyarakat Suku Bajo yang ada di Desa Pulau Bungin Kecamatan Alas Kabupaten Sumbawa adalah karena didasari oleh sifat kekeluargaan yang tinggi, nilai solidaritas yang tinggi, dan pembagian kerja yang merata. Selain itu, atas dasar perluasan wilayah yang beriringan dengan laju pertumbhan penduduk, mereka pun didesak oleh suatu kebutuhan, baik kebutuhan berupa lahan untuk membangun rumah, maupun kebutuhan dari aspek lain seperti pendidikan dan pemenuhan kebutuahn lainya. Namun, jika dikaitkan dengan kondisi geografis Pulau Bungin yang letaknya jauh dari desa-desa lain, tentu mereka sulit untuk memenuhi berbagai kebutuhan atau harapan-harapan mereka dari berbagai aspek kehidupan fisik dan sosial. Sebab untuk melakukan interaksi dengan pihak desa luar, warga setempat harus mempergunakan alat transportasi laut yang berupa perahu atau sampan, sementara sementara kondisi air laut atau cuaca di laut tidak selamanya bersahabat. Hal ini inilah yang memicu semangat mereka untuk saling berpikr dan bekerjasama agar mereka dapat bertindak secara swasembada untuk membangun sebuah jalan lintas darat di atas laut yang menghubungkan dengan pusat ibu kota dari Kecamatan Alas Sumbawa.
Setelah warga masyarakat Desa ulau Bungin berhasil membangun jembatan atau jalan litas darat yang membentang di atas laut, mereka dapat merasakan pengembangan seperti terbangunnya sarana dan prasarana pendidikan, perekonomian, alat tarnsprotasi yang berupa kendaraan darat, dan berbagai usaha perdagangan yang dapat dikembangkan, baik dengan usaha yang dikaitkan dengan hasil laut, maupun yang berupa usaha perdagangan lainnya.

\section{KESIMPULAN}

- Perluasan wilayah melalui dengan pengumpulan batu karang dari laut sebagai bahan timbunan untuk rumah panggung khas Sulawesi Selatan di tepi laut Desa Pulau Bungin Kecamatan Alas Kabupaten Sumbawa, yang mana di disebabkan oleh kebutuhan lahan tempat tinggal oleh warga setempat yang ingin menetap, yang akan membentuk keluarga baru, serta akibat pertumbuhan penduduk..

- Proses pengembangan masyarakat Suku Bajo terwujud atas dasar rasa solidaritas yang tinggi, kekeluargaan, pembagian kerja sehingga mereka saling bahumembahu dalam membangun wilayah mereka baik dari aspek pendidikan, ekonomi, dan sosial lainnya dengan lebih awal membangun infrastruktur jalan darat di atas laut yang bertujuan untuk beriteraksi dengan desa-desa luar sehingga pemenuhan kebutuhan dalam berbagai aspek tercapai.

SARAN

- Agar masyarakat dapat memperhatikan keseibangan jumlah penduduk dengan luas lahan tempat tinggal dengan jumlah penduduk.

- Agar pemerintah lebih giat dalam memperhatikan betapa pentingnya pengembangan suatu wilayah, yang mana dengan tetap memperhatikan keseimbangan antara jumlah penduduk dengan luas wilayah hunian, dan juga mampu mengembangkan masyarakat dari berbagai aspek dengan lebih awal menyelesaikan penghambat pembangunan. .

- Agar pada masyarakat, khususnya bagi warga pesisir agar dapat lebih 
menngkatkan rasa persaudaraan, kkeluargaan, solidaritas yang inggi, pembagian kerja dalam mengembangkan kehidupan sosial di di suatu wilayah.

\section{DAPTAR PUSTAKA}

Ahmad Tanzeh, Pengantar Metode Penelitian, (Yogyakarta: Teras, 2009).

Husaini Usman dan Purnomo Setiadi Akbar, "Metode Penelitian Sosial"( Jakarta: Bumi Aksara, 1996).

M. Idrus, Metode Penelitian Ilmu-ilmu Sosial: Pendekatan Kualitatif dan Kuantitatif, (Yogyakarta: UII Press, 2007).

KOnsep Tradisi dalam bahasa Istilah, https://dewasastra.wordpress.com/2012/ 04/04/tradisi-bahasa-dan-istilah/

POla Pemukiman Penduduk, https://sumberbelajar.belajar.kemdikbud .go.id/sumberbelajar/tampil/PolaPemukiman-Penduduk2008/konten5.html

Kamus Besar Bahasa Indonesia: Tim Penyusun Kamus Besar Bahasa, (Ed-3. Cet-1 Jakarta ; Balai Pustaka, 2001)Siti Nur Aryani: Oposisi Paska Tradisi. Islam agamaperlawanan.(online).(http//Islamli beral.com/id/indeks) diakses 8 Agustus 2003Drs. Abdul Syani. Sosiologi dan Perubahan Masyarakat (Cet-1.Dunia Pustaka

KOnsep Tradisi dalam bahasa Istilah, https://dewasastra.wordpress.com/2012/ 04/04/tradisi-bahasa-dan-istilah/

POla Pemukiman Penduduk, https://sumberbelajar.belajar.kemdikbud .go.id/sumberbelajar/tampil/PolaPemukiman-Penduduk2008/konten5.html 